\title{
Ascetismo, Gênero e Poder no Baixo Império Romano: Paládio de Helenópolis e o status das Devotas Cristãs
}

\author{
Gilvan Ventura da Silva*
}

Resumo: As diversas modalidades de ascetismo feminino que vigoraram nas comunidades cristãs ao longo dos três primeiros séculos do Império tenderão a se integrar numa nova experiência religiosa que começa a se esboçar por volta de 270 para alcançar uma expansão considerável no final do Mundo Antigo: o monacato. Mediante a análise da História Lausíaca, de Paládio de Helenópolis, obra escrita por volta de 420, investigamos a posição social das ascetas e o tipo de atuação que desempenharam no interior de um movimento dominado pelos homens, como foi o movimento monástico. Além disso, analisamos a capacidade das mulheres de exercer alguma modalidade de poder no âmbito das suas comunidades locais em comparação aos homens divinos cristãos do Baixo Império.

Palavras-chave: Baixo Império, Paládio de Helenópolis, Ascetismo Feminino

\section{Introdução}

As diversas modalidades de ascetismo feminino que vigoraram nas comunidades cristãs ao longo dos três primeiros séculos do Império tenderão a se integrar numa nova experiência religiosa que começa a se esboçar por volta de 270 para alcançar uma expansão considerável no final do Mundo Antigo: o monacato. O movimento monástico apresenta como expoentes Antônio e Pacômio, célebres ascetas egípcios responsáveis pela fundação ou ao menos pela popularização dos dois ramos principais de experiência monástica: o anacoretismo e o cenobitismo. ${ }^{1}$ A atuação religiosa de Antônio, filho de um abastado proprietário da região do Faium, no Baixo Egito, se inicia por volta de 270. Ao se tornar órfão, Antônio decide abandonar a vida na aldeia para se refugiar no deserto, não sem antes distribuir seus recursos aos pobres e instalar sua irmã numa "casa de virgens” para ser educada, ${ }^{2}$ o que nos permite concluir com segurança pela existência, no século III, de associações de mulheres devotas fora do âmbito familiar. A opção de vida de Antônio é, como se sabe, imitada por muitos outros, ávidos de experimentar uma devoção mais rigorosa, num claro prolongamento do modus vivendi dos mártires, não sendo por acaso que o ascetismo monástico é, em muitas obras do período, qualificado como um martírio branco por oposição ao martírio sangrento dos 
antigos confessores. ${ }^{3}$ Desse modo, logo os territórios da Nítria, da Sceta e da Célia serão invadidos por anacoretas que buscarão, na solidão e na rudeza da vida no deserto, a vitória contra as imperfeições mundanas e a elevação da alma.

Ainda que tenhamos conhecimento da existência de um anacoretismo feminino, a modalidade mais difundida de ascese monástica entre as mulheres foi mesmo o cenobitismo. O monacato cenobítico, como dissemos, se encontra associado a Pacômio, um pagão que após o batismo, em 313, se dedica a fundar associações (koinoniai) de monges em Tabenesi, no sul do Egito, instituindo uma modalidade de vida comunitária pautada no trabalho coletivo e na obediência absoluta aos superiores. Quando da morte de Pacômio, em 346, os pacomianos (ou tabenesiotas) já contavam com nove mosteiros masculinos e dois mosteiros femininos que constituíam uma verdadeira ordem. A partir desse momento, os mosteiros se tornarão um ponto de convergência para as virgens, viúvas e diaconisas, que deixarão seus lares a fim de viver reclusas, sob a liderança de uma amma. ${ }^{4}$ A força centrípeta exercida pelos mosteiros sobre as distintas modalidades de ascetismo feminino foi tão intensa que as diaconisas acabaram sendo assimiladas às monjas, o que contribuiu para enfraquecer a atuação das mulheres junto às igrejas locais. O termo final desse processo foi o desaparecimento do diaconato feminino em finais do século XI. ${ }^{5}$ Desse modo, no que diz respeito às mulheres, a expansão do movimento monástico produziu uma autêntica redefinição na maneira pela qual praticavam o ascetismo, como nos dão testemunho diversas obras provenientes do Baixo Império, entre as quais se inclui a História Lausíaca escrita por Paládio, bispo de Helenópolis.

\section{Paládio e a História Lausíaca}

Os monges do final da Antigüidade eram celebrados como "homens santos” ou divinos (theioi andres), o que representou a vertente cristã de sacralização de seres humanos excepcionais que começa a ganhar fôlego na sociedade romana na passagem do II para o III século. De fato, entre 210 e 220, Filóstrato, um autor do círculo de Júlia Domna, escreve a Vida de Apolônia de Tiana, na qual o filósofo e mago é retratado como um emissário divino, quase um êmulo de Cristo, capaz de realizar prodígios e maravilhas e adepto de um rigoroso ascetismo. ${ }^{6}$ Entre os cristãos, os mártires representaram, seguramente, a primeira categoria de homens divinos após os apóstolos, exercendo por séculos um notável fascínio sobre a ecclesia. Com o fim da Grande Perseguição e a conversão de Constantino, no entanto, não havia mais lugar no mundo 
romano para indivíduos dispostos à imolação pública em nome da fé que professavam. Diante da acomodação que logo se estabelece entre a elite eclesiástica e o poder imperial, o que significou ao mesmo tempo o início de uma era de estabilidade para a Igreja e o arrefecimento do ardor de purificação diante do retorno iminente de Cristo, um contingente cada vez maior de indivíduos, certamente motivados por um desejo de viver do modo mais literal possível os ensinamentos de Jesus contidos nos Evangelhos, decide romper com os laços rotineiros de sociabilidade e adentrar o deserto, passando então a praticar toda sorte de penitências e mortificações na ânsia de elevação espiritual. ${ }^{7} \mathrm{O}$ monacato pode assim ser qualificado como o mais notável movimento ascético da história da Igreja, não apenas em função da quantidade de pessoas que mobilizou, mas igualmente do impacto que produziu sobre a sensibilidade religiosa cristã por séculos a fio. Doravante esses homens, conhecidos como os Padres do Deserto, seja na qualidade de eremitas enclausurados em celas escavadas nas rochas ou reunidos em comunidades regidas por uma regra e tendo à frente um superior, se converterão nos homens divinos cristãos por excelência, os legítimos sucessores dos mártires e, como estes, candidatos à santificação após a morte. ${ }^{8}$

A fim de dar publicidade às façanhas espirituais dos ascetas e desse modo difundir um determinado modelo de virtude cristã, logo veremos o aparecimento de obras concernentes à vida e aos milagres dos monges cristãos que prefiguram as hagiografias, um gênero literário destinado a exercer uma duradoura influência sobre a mentalidade medieval. Destas, talvez uma das mais célebres seja a Vida de Antônio, escrita por Atanásio em meados do século IV, na qual é descrita a luta incessante do patriarca dos anacoretas contra os demônios do deserto que o atormentavam. A perspectiva, nesse caso, é eminentemente aretológica, procurando-se evidenciar as virtudes da personagem, que se dedica a dar combate às forças do mal. ${ }^{9}$ Por vezes, as façanhas dos monges eram reunidas em compêndios que davam notícia, de maneira sucinta, sobre os principais aspectos da vida deste ou daquele asceta, sem dúvida com o propósito de informar a audiência sobre a exuberância e vitalidade do movimento monástico. Dentre esses compêndios poderíamos citar a História dos monges do Egito, de autoria ignorada; a História religiosa, de Teodoreto de Ciro; e, no que nos interessa mais de perto, a História Lausíaca, escrita por Paládio de Helenópolis. Nascido na Galácia em 363 ou 364, Paládio tornou-se monge em 386, tendo vivido cerca de quatorze anos em peregrinação entre os ascetas da Palestina e do Egito, o que lhe permitiu travar contato direto com diversos expoentes do movimento monástico à 
época, como Dídimo, o Cego, Evágrio Pôntico e Melânia. Por volta de 400, é consagrado bispo de Helenópolis, na Bitínia. Tendo sustentado a causa de João Crisóstomo no embate deste com os círculos governamentais de Constantinopla, Paládio termina preso e exilado no Egito por determinação de Arcádio. Após a libertação, decide retornar à sua terra natal, a Galácia, assumindo o bispado de Aspuna em 417. Não conhecemos a data exata da sua morte, mas esta se deu antes de 431, pois nessa ocasião Eusébio já aparece à frente da sé de Aspuna.

Por volta de 419-420, Paládio escreve a História Lausíaca, obra que vai dedicada a Lauso, alto funcionário da corte de Teodósio II. A Historia Lausíaca é tributária, em larga medida, da História dos monges do Egito, reelaborada por Rufino entre 404 e 410 e enriquecida com as memórias de viagem do próprio Paládio pelo Egito e Palestina. A obra recebeu uma excelente acolhida nos círculos monásticos, sendo logo traduzida para o latim e para diversas línguas orientais. ${ }^{10} \mathrm{Na}$ História Lausíaca, o autor se dedica a reportar, em setenta e um capítulos, as ações piedosas de um conjunto de monges do Egito e da Síria-Palestina, a maior parte constituída por homens. No entanto, ao longo da obra são registrados cerca de trinta casos de mulheres que abraçaram a vida ascética. Em virtude disso é que decidimos investigar a que categoria ou categorias de mulheres Paládio se refere e a maneira pela qual estas aparecem retratadas na obra. Nosso objetivo inicial era duplo: em primeiro lugar, determinar a posição social das ascetas e o tipo de atuação que desempenharam no interior de um movimento dominado pelos homens. Em segundo lugar, identificar se a opção pela vida ascética por parte dessas mulheres teria produzido uma equiparação, ainda que relativa, com os homens divinos cristãos, o que implicava evidentemente investigar a sua capacidade de exercer algum tipo de poder no âmbito de suas respectivas comunidades. No que diz respeito ao primeiro objetivo, logo de início constatamos, na História Lausíaca, uma nítida polarização entre as mulheres de filiação aristocrática e as mulheres comuns, do povo, assunto do qual passamos a tratar.

\section{O status das devotas na História Lausíaca}

Paládio menciona um conjunto de mulheres que, fazendo parte da elite, se notabilizaram pela extraordinária devoção à causa cristã. Estas são as denominadas kanonikai, pois se julgava que estavam comprometidas com um cânone, uma regra estrita de vida que as distinguia das demais. ${ }^{11}$ Entre as kanonikai mencionadas na História Lausíaca, somente uma, Sabaniana, é natural de Antioquia. Todas as demais 
pertencem aos círculos aristocráticos de Roma, seja na condição de esposas, filhas ou viúvas de destacados membros da elite romana (ver Quadro 1). Venéria, por exemplo, é esposa do comes Valovico. Melânia, a Antiga, é filha do ex-cônsul Marcelino enquanto Olímpia é filha do ex-comes Seleuco. Embora Paládio não nos informe com precisão acerca dos atos piedosos praticados por diversas dessas mulheres, aquelas para as quais possuímos dados mais consistentes indicam que a principal modalidade de ascetismo que vigorava entre as aristocratas era a pobreza. De fato, na qualidade de detentoras de um vasto patrimônio, as devotas da aristocracia se tornam célebres por consumir toda a sua riqueza na conservação de igrejas, mosteiros e hospedarias e no socorro prestado a monges, enfermos e prisioneiros. Entre elas, o caso mais conhecido é o de Melânia, a Jovem, que teria distribuído entre o Egito, Antioquia e Palestina 45 mil moedas de ouro. Um outro montante foi destinado às igrejas do Ocidente. Melânia vendeu ainda suas possessões na Espanha, Aquitânia, Tarragona e Gália, retendo apenas aquelas da Sicília, Campânia e África, cujos rendimentos destinou à manutenção de conventos. Além disso, providenciou a libertação de 8 mil escravos, dentre os que desejavam a alforria. Os demais foram deixados aos cuidados de seu irmão, o que nos permite ter uma idéia da extensão da sua riqueza. ${ }^{12}$ Melânia evidentemente é um caso importante, mas não único. Paula, responsável pelo funcionamento de um mosteiro com 50 virgens na Palestina; Asela, uma virgem reconhecida como patrona de conventos ${ }^{13}$ e Melânia, a Antiga, fundadora de um mosteiro para mulheres em Jerusalém, ${ }^{14}$ cumprem, do mesmo modo, o papel de patronas veneráveis da Igreja.

Aliada à pobreza, principal virtude dessas mulheres, temos alguns outros atributos que auxiliam, de modo secundário, na composição da sua imagem. As aristocratas são lembradas como mulheres que observavam a castidade e o jejum e se ocupavam com trabalhos manuais. Muito embora a maioria das mulheres da aristocracia a respeito das quais possuímos informações mais seguras tenha optado por dedicar-se integralmente à vida religiosa, o que as torna modelos de virtude e de devoção, isso não significou, a princípio, a reclusão perpétua em um mosteiro. Nesse sentido, o caso de Melânia, a Antiga, é bem ilustrativo acerca da capacidade de intervenção dessas mulheres na sociedade de seu tempo. Quando o prefeito do Egito baniu um grupo de aproximadamente vinte monges para a Palestina, Melânia se encarregou pessoalmente de socorrê-los no exílio, o que lhe valeu uma prisão por parte do consular da Palestina, desejoso de obter, mediante extorsão, algum benefício. Melânia se defende perante o tribunal evocando a sua condição de nobreza. No fim, é absolvida e recebe a permissão 
para continuar assistindo os monges. Numa outra ocasião, Melânia, tomando conhecimento de que sua neta mostrava-se inclinada a abraçar a vida ascética, viaja às pressas de Cesaréia da Palestina a Roma a fim de evitar que ingressasse em alguma das seitas heréticas que então abundavam na Cidade Eterna. A visita de Melânia a Roma se converte em uma verdadeira ação missionária, pois não apenas obtém a conversão da neta, mas também da sobrinha, Avita; do marido desta, Aproniano e da sua nora, Albina, persuadindo todos a distribuir os seus bens e a abraçar a vida monástica. Segundo Paládio, a atuação de Melânia suscitou uma feroz reação da parte das famílias senatoriais romanas, que tentaram a todo custo evitar a perda de alguns dos seus membros mais ilustres, embora sem sucesso. ${ }^{15}$

De um modo geral, podemos afirmar que, em Paládio, o principal mérito das kanonikai foi ter renunciado à sua posição confortável e colocado o seu extenso patrimônio a serviço da Igreja, incluindo a fundação de mosteiros, fator responsável, no Baixo Império, por uma nítida expansão do monacato feminino. Para Monique Alexandre, ${ }^{16}$ a intervenção das aristocratas na vida da Igreja dos séculos IV e V tendeu a eclipsar os outros grupos sociais. À luz da leitura da História Lausíaca, no entanto, essa afirmação deve ser considerada apenas parcialmente correta. É fato que todas as mulheres da elite mencionadas por Paládio são identificadas pelos seus respectivos nomes e, na maioria das vezes, têm a filiação assinalada a fim de evidenciar a sua condição nobre, ao passo que outras mulheres, de status inferior, surgem amiúde como anônimas na narrativa (ver Quadro 2). E, no entanto, elas estão lá, presentes. Suas façanhas são consideradas dignas de figurar no inventário dos santos do deserto, mesmo que o nome de algumas delas tenha sido esquecido e a despeito da posição subalterna que ocupavam na sociedade romana tardia. Sua atuação, comparada à das kanonikai, era sem dúvida bem menos arrojada. Mulheres comuns, do povo, exerciam a sua devoção de maneira silenciosa, recatada, mas em algumas situações se distinguiam por uma admirável vocação ascética. Assim ocorre com Alexandra, uma obscura criada de Alexandria ${ }^{17}$ que permaneceu confinada por dez anos numa tumba, na mais completa solidão, mantendo contato com o mundo exterior apenas através de uma abertura, por onde recebia alimento. Seu tempo, conforme depoimento de Melânia, a Antiga, que teve a oportunidade de visitá-la certa vez, era consumido em oração constante, meditação e trabalhos de tecelagem. Já Amma Talis, a superiora do mosteiro pacomiano em Antinoé, na Tebaida, teria praticado o ascetismo por 80 anos. ${ }^{18}$ Paládio conserva 
também, no capítulo LXIX, a lembrança de uma virgem anônima que, após ter dado à luz a um filho, jejuou por trinta anos como penitência por seu pecado.

Dentre todas as devotas do povo mencionadas na História Lausíaca, no entanto, nenhuma apresenta um perfil mais extraordinário do que Piamon, uma virgem egípcia que coabitava com sua mãe. Conta-nos Paládio que Piamon era conhecida em sua localidade pelo dom da profecia. Durante as cheias do Nilo, ocorria por vezes que uma aldeia atacava a outra na disputa pelo uso da água do rio. Numa dessas cheias, um anjo revelou a Piamon que os homens de uma aldeia vizinha estavam a caminho, armados com lanças e clavas, para destruir sua aldeia. A virgem se dirige então aos líderes locais, reportando a visão que tivera. A reação dos aldeões é no mínimo inusitada: temerosos em lidar com vizinhos que julgavam por demais violentos, solicitam a Piamon que vá ao encontro deles a fim de impedir que invadam a aldeia. A virgem não atende a solicitação, refugiando-se em sua casa, onde passa a noite em oração. Ao amanhecer, as preces de Piamon são ouvidas e os invasores caem por terra, imóveis, sendo forçados a celebrar a paz graças à intervenção da virgem, que é por todos exaltada. ${ }^{19}$ A história da camponesa egípcia é surpreendente pelo fato de que, entre todas as mulheres das quais nos fala Paládio, Piamon é a única que aparece executando atos taumatúrgicos, uma habilidade bastante comum entre os theioi andres do Império Romano. De fato, os homens divinos, pagãos ou cristãos, não importa, se notabilizaram em grande parte devido à capacidade de realizar atos mágicos e miraculosos, manipulando assim sobre a terra aspectos do sagrado, o que nos remete a uma modalidade importantíssima de exercício do poder na sociedade romana. ${ }^{20}$ No caso da História Lausíaca, o caráter excepcional de Piamon contribui apenas para evidenciar o quanto as mulheres se encontram privadas dessa capacidade de intervenção, que permanece circunscrita, na sua quase-totalidade, ao universo masculino. Diante de uma constatação como essa, torna-se oportuno refletir sobre como se processa a construção das relações de gênero na obra de Paládio, pois somente mediante o confronto entre a atuação dos monges e a das monjas teremos condições de iluminar com maior propriedade o lugar ocupado pelas devotas cristãs dentro do movimento monástico do Baixo Império.

Quadro 1: as devotas aristocráticas

\begin{tabular}{|c|c|c|c|c|}
\hline PERSONAGEM & LOCALIDADE & STATUS & $\begin{array}{c}\text { PRÁTICAS } \\
\text { ASCÉTICAS }\end{array}$ & $\begin{array}{c}\text { ATRIBUTOS E AÇÕES } \\
\text { PIEDOSAS }\end{array}$ \\
\hline Paula & Roma & viúva de Toxotio & & castíssima \\
\hline
\end{tabular}




\begin{tabular}{|c|c|c|c|c|}
\hline & & & & $\begin{array}{l}\text { fundação de um convento } \\
\text { com } 50 \text { virgens }\end{array}$ \\
\hline Veneria & & $\begin{array}{c}\text { esposa do comes } \\
\text { Valovico }\end{array}$ & pobreza & \\
\hline Teodora & & esposa de tribuno & pobreza & partilha dos bens \\
\hline Hosia & & & & venerável \\
\hline Adolia & & irmã de Hosia & & \\
\hline Basianilla & & $\begin{array}{l}\text { mulher do general } \\
\text { Candidiano }\end{array}$ & & ardente praticante da virtude \\
\hline Fotina & & $\begin{array}{c}\text { virgem } \\
\text { irmã do sacerdote } \\
\text { Theoctistos }\end{array}$ & & \\
\hline Sabaniana & Antioquia & $\begin{array}{c}\text { Diaconisa } \\
\text { sobrinha de João de } \\
\text { Constantinopla }\end{array}$ & & conversa familiar com Deus \\
\hline Asela & Roma & & $\begin{array}{c}\text { reclusão num } \\
\text { convento }\end{array}$ & $\begin{array}{c}\text { beleza } \\
\text { manutenção de mosteiros }\end{array}$ \\
\hline Avita & & esposa de Aproniano & $\begin{array}{l}\text { continência (em } \\
\text { acordo com o } \\
\text { marido) } \\
\end{array}$ & \\
\hline $\begin{array}{l}\text { Melânia, a } \\
\text { Velha }\end{array}$ & Roma & $\begin{array}{c}\text { viúva } \\
\text { filha do ex-cônsul } \\
\text { Marcelino }\end{array}$ & pobreza & $\begin{array}{c}\text { partilha dos bens } \\
\text { peregrinação aos monges do } \\
\text { Egito } \\
\text { auxílio aos monges do Egito } \\
\text { exilados } \\
\text { fundação de um mosteiro em } \\
\text { Jerusalém } \\
\text { auxílio aos bispos, monges e } \\
\text { virgens que visitavam } \\
\text { Jerusalém } \\
\text { reconciliação do cisma de } \\
\text { Paulino } \\
\text { socorro a igrejas, mosteiros, } \\
\text { estranhos e prisioneiros } \\
\text { conversão de diversos } \\
\text { membros da aristocracia }\end{array}$ \\
\hline Silvania & Roma & Virgem & $\begin{array}{l}\text { nunca tocou em água } \\
\text { nunca descansou } \\
\text { numa cama ou liteira }\end{array}$ & $\begin{array}{c}\text { amante da literatura } \\
\text { lia cada livro } 7 \text { ou } 8 \text { vezes }\end{array}$ \\
\hline Olímpia & Roma & $\begin{array}{c}\text { virgem } \\
\text { filha do ex-comes } \\
\text { Seleuco }\end{array}$ & pobreza & $\begin{array}{c}\text { partilha dos bens } \\
\text { instrução de mulheres } \\
\text { reverência aos sacerdotes e } \\
\text { bispos } \\
\text { tida entre os confessores }\end{array}$ \\
\hline Cândida & & & $\begin{array}{c}\text { pobreza } \\
\text { trabalho contínuo na } \\
\text { moenda } \\
\text { abstenção do sangue } \\
\text { e da vida } \\
\text { ingestão de vinho } \\
\text { acre e pão duro }\end{array}$ & $\begin{array}{c}\text { partilha dos bens } \\
\text { honra às igrejas e bispos } \\
\text { instrução da filha na } \\
\text { virgindade }\end{array}$ \\
\hline Gelásia & & Virgem & & extrema paciência \\
\hline $\begin{array}{l}\text { Melânia, a } \\
\text { jovem }\end{array}$ & Roma & esposa de Piniano & $\begin{array}{l}\text { continência (em } \\
\text { acordo com o } \\
\text { marido) } \\
\text { pobreza } \\
\text { libertação de } 8 \text { mil } \\
\text { escravos } \\
\text { jejum } \\
\text { trabalho manual } \\
\text { junto com as } \\
\text { escravas }\end{array}$ & $\begin{array}{c}\text { partilha dos bens } \\
\text { mais virtuosa entre as } \\
\text { mulheres } \\
\text { manutenção de mosteiros }\end{array}$ \\
\hline Albina & Roma & mãe de Melânia & pobreza & partilha dos bens \\
\hline
\end{tabular}


Quadro 2: as devotas do povo

\begin{tabular}{|c|c|c|c|c|c|}
\hline PERSONAGEM & LOCALIDADE & STATUS & $\begin{array}{l}\text { POSIÇÃO } \\
\text { SOCIAL }\end{array}$ & $\begin{array}{l}\text { PRÁTICAS } \\
\text { ASCÉTICAS }\end{array}$ & $\begin{array}{c}\text { ATRIBUTOS E } \\
\text { AÇÕES } \\
\text { PIEDOSAS } \\
\end{array}$ \\
\hline Alexandra & Alexandria & virgem & criada & $\begin{array}{l}\text { reclusão numa tumba } \\
\text { oração constante } \\
\text { tecelagem } \\
\text { meditação }\end{array}$ & \\
\hline $\begin{array}{l}\text { A virgem } \\
\text { pecadora }\end{array}$ & Jerusalém & virgem & & $\begin{array}{l}\text { vestido de aniagem } \\
\text { reclusão numa cela }\end{array}$ & \\
\hline Piamon & Egito & virgem & camponesa & $\begin{array}{c}\text { jejum } \\
\text { tecelagem }\end{array}$ & $\begin{array}{c}\text { profecia } \\
\text { taumaturgia }\end{array}$ \\
\hline A virgem louca & Egito & virgem & & $\begin{array}{l}\text { trabalho subalterno } \\
\text { uso de trapos } \\
\text { refeição solitária } \\
\text { reserva ao falar }\end{array}$ & $\begin{array}{l}\text { mais piedosa que } \\
\text { Piterum, o monge }\end{array}$ \\
\hline Amma Talis & Antinoé & & & ascetismo por 80 anos & amada pelas monjas \\
\hline Taor & Antinoé & virgem & & $\begin{array}{l}\text { nunca portou um } \\
\text { hábito, capuz ou } \\
\text { sandálias novas } \\
\text { permanência contínua } \\
\text { no mosteiro } \\
\text { uso de trapos } \\
\text { trabalho incessante }\end{array}$ & beleza \\
\hline $\begin{array}{l}\text { A monja } \\
\text { anônima }\end{array}$ & & virgem & & 60 anos de ascetismo & \\
\hline $\begin{array}{l}\text { Virgem de } \\
\text { Atanásio }\end{array}$ & Alexandria & & & vida solitária & $\begin{array}{c}\text { Beleza } \\
\text { cuidado com } \\
\text { Atanásio }\end{array}$ \\
\hline Juliana & Cesaréia & virgem & & & $\begin{array}{c}\text { instruída } \\
\text { devota } \\
\text { cuidou de Orígenes }\end{array}$ \\
\hline Magna & Ancira & $\begin{array}{l}\text { virgem ou } \\
\text { viúva }\end{array}$ & & $\begin{array}{c}\text { continente (repúdio ao } \\
\text { marido) }\end{array}$ & $\begin{array}{c}\text { conversação } \\
\text { apropriada } \\
\text { auxílio aos } \\
\text { hospitais, pobres e } \\
\text { bispos } \\
\end{array}$ \\
\hline $\begin{array}{l}\text { A monja que } \\
\text { pecou }\end{array}$ & & virgem & & $\begin{array}{c}\text { ascetismo por } 9 \text { ou } 10 \\
\text { anos } \\
\text { jejum } \\
\text { auxílio aos doentes e } \\
\text { mutilados } \\
\end{array}$ & \\
\hline
\end{tabular}

\section{Ascetismo e relações de gênero}

A sociedade romana tradicional, como se sabe, sempre apresentou um caráter patriarcal, não sendo por acaso que Montserrat $^{21}$ a qualifica como uma sociedade "falocêntrica” na qual a recorrência de representações do órgão sexual masculino é, em última análise, uma demonstração ostensiva do poder exercido pelos homens em Roma. Do mesmo modo, nas comunidades judaicas, as mulheres se encontravam submetidas aos homens, os únicos que podiam aprender a Torá e atuar como rabinos. ${ }^{22}$ Contra esse 
pano de fundo nitidamente misógino, o cristianismo não apresentou nenhuma proposta revolucionária, conformando-se de modo previsível às antigas estruturas de dominação masculina existentes de um lado e de outro do Mediterrâneo. A bem da verdade, a única inovação significativa nesse domínio foi justamente a ascensão, nas comunidades cristãs dos primeiros tempos, de mulheres exercendo funções de liderança religiosa e revestindo carismas, ascensão essa estimulada pela profusão, à época, de seitas gnósticas de matiz cristão que reservavam às mulheres uma posição de destaque na liturgia. A possibilidade de as mulheres virem a desempenhar na ecclesia um papel no mínimo equivalente ao dos homens logo se converteu em um notável catalisador para os líderes religiosos, notadamente os bispos, que trataram de se organizar em concílios com o propósito de bloquear uma ameaça iminente, ao mesmo tempo em que reforçavam a sua preeminência, instituíam a hierarquia eclesiástica e fixavam o que era canônico e ortodoxo em oposição ao que era apócrifo e herético. E, no entanto, as mulheres constituíam uma força dentro da Igreja que não poderia em absoluto ser ignorada. Sua devoção à causa cristã, seu ardor missionário e sua disposição à prática do ascetismo, especialmente no que dizia respeito à virgindade e à continência, eram contribuições importantes para a afirmação dos valores cristãos, não obstante o erro fundamental cometido por Eva. Nesse sentido, urgia redefinir o lugar ocupado pela mulher no plano de salvação, o que implicava refletir sobre a sua própria natureza. Afinal de contas, haveria de fato alguma diferença entre homens e mulheres no que diz respeito ao exercício da fé? Seriam as mulheres tão habilitadas à virtude quanto o homem? A resposta, nesse caso, é sim e não.

No IV século, parece já ter se estabelecido entre os Padres da Igreja certo consenso quanto à capacidade de a mulher superar o estigma do pecado lançado sobre ela por Eva e com isso se equiparar ao homem. De acordo com Clemente de Alexandria, a mulher possuía uma capacidade intelectiva para a vida virtuosa idêntica à do homem, não havendo, fora do matrimônio, distinção entre macho e fêmea, uma vez que era permitido a ambos desempenhar tarefas comuns. ${ }^{23}$ A opinião de Clemente, é certo, comportava uma aproximação um tanto quanto perigosa entre homens e mulheres, o que logo foi mitigado pelas reflexões de outros teólogos. Segundo Jerônimo, talvez o mais influente defensor da virgindade e da continência entre os Padres do Ocidente, a mulher era a imagem por excelência da lascívia e um ser débil física e moralmente em comparação ao homem. No entanto, mediante o exercício de um rigoroso ascetismo, as mulheres teriam a oportunidade de reparar a debilidade que traziam desde o nascimento. 
As que assim procederam são celebradas por Jerônimo como acima dos homens em função do desafio que tiveram de superar. ${ }^{24}$ Em Paládio, por sua vez, o que observamos é uma inclinação do autor a concordar com o argumento segundo o qual a mulher (a mulher praticante do ascetismo, bem entendido) seria tão virtuosa quanto o homem. Tanto é assim que no capítulo XLI da História Lausíaca, ao tratar das virgens e viúvas da aristocracia, Paládio afirma a necessidade de mencionar "algumas mulheres com qualidades viris às quais Deus atribuiu tarefas iguais às tarefas dos homens, de modo que ninguém pudesse dizer que as mulheres são muito débeis para praticar a virtude perfeitamente”. Numa outra passagem, Paládio narra o caso de uma monja que, fingindo ser louca, era, na realidade, mais santa do que Piterum, um célebre anacoreta que habitava as margens do Mar Vermelho. ${ }^{25}$ Tomando por base os casos narrados, Paládio concorda que as mulheres são tão aptas quanto os homens à elevação espiritual, não havendo nada que impeça uma mulher de exibir “qualidades viris” que lhe permitam praticar as mesmas ações que os homens. Deixando de lado o plano doutrinal, teológico e passando para o plano disciplinar, no entanto, a situação se altera radicalmente, pois o que se verifica na História Lausíaca é a tutela recorrente do homem sobre a mulher associada à manutenção dos códigos cristãos de segregação sexual que remontam pelo menos ao século III.

Com raríssimas exceções, as devotas retratadas por Paládio exercem o ascetismo secundadas sempre por uma figura masculina. Paula e Melânia, a Antiga, por exemplo, a despeito da posição social da qual desfrutam, se fazem acompanhar por prelados que as auxiliam nas atividades filantrópicas que executam. Paula é aconselhada por Jerônimo, ao passo que Melânia tem em Rufino de Aquiléia um companheiro inseparável. A relação entre a rica devota e seu conselheiro espiritual, entretanto, mostrava-se por vezes conflituosa. Paládio acusa Jerônimo de atrapalhar, com sua influência nefasta, o desenvolvimento espiritual de Paula, por quem, segundo o autor, nutre uma profunda inveja. ${ }^{26}$ Ascetas como Olímpia e Cândida, por sua vez, são celebradas por guardarem uma profunda reverência pelos bispos e sacerdotes. Outras só tiveram a sua santidade reconhecida mediante a intervenção de um homem. Esse é o caso da virgem que fingiu ser louca, ao qual já aludimos. Desprezada pelas companheiras do mosteiro, que a consideravam inepta, a monja foi revelada uma amma, ou seja, uma mãe espiritual, pelo monge Piterum, que de maneira absolutamente insólita requer a sua bênção. Daí em diante, a virgem experimenta um assédio tão intenso que não lhe resta outra saída a não ser abandonar o mosteiro. ${ }^{27}$ Em outras circunstâncias, a 
asceta recebe, por ocasião da morte, a assistência de um monge. Assim procedeu Colito, que revela a uma monja com sessenta anos de vida ascética a proximidade do fim, acompanhando com preces os seus últimos momentos. ${ }^{28}$ No caso das devotas da aristocracia, elas são lembradas também como responsáveis pelo sustento dos monges, a exemplo de Melânia, a Antiga, que se incumbiu de socorrer os ascetas banidos pelo prefeito do Egito. Desse modo, em múltiplas ocasiões as mulheres cristãs gravitam em torno dos homens, sejam estes superiores hierárquicos, guias espirituais ou desvalidos que reclamam a assistência feminina.

A História Lausíaca, por outro lado, nos deixa entrever como o movimento monástico se adequa muitíssimo bem ao ideal de segregação sexual que se afirma na passagem do II para o III século. Desafiada pela crescente inserção feminina na vida pública da Igreja, a hierarquia eclesiástica se preocupou em despojar a mulher de qualquer carisma sacerdotal, ao mesmo tempo em que investia em práticas que tendiam a ressaltar a distinção espacial entre os sexos. Assim é que Hipólito de Roma, no século III, proibia que homens e mulheres se saudassem reciprocamente na celebração dominical. Na realidade, já em meados do século II começamos a observar, no recinto da igreja, a separação entre homens e mulheres, retomando-se assim um antigo costume judaico observado nas sinagogas. ${ }^{29}$ A instituição do diaconato feminino, por sua vez, segue essa mesma lógica de segregação na medida em que as diaconisas eram ordenadas para assistir as próprias mulheres, de modo que evitasse que um homem fosse obrigado a fazê-lo. ${ }^{30} \mathrm{O}$ esvaziamento da atuação pública das mulheres e o seu isolamento diante dos homens foram acompanhados pela afirmação de um notável discurso de exaltação da virgindade e da continência como atributos por excelência da condição feminina que atendiam de modo excepcional aos interesses da elite eclesiástica. $^{31}$ Exercendo a castidade e praticando a oração, a virgem ou viúva não apenas contribuía para a salvação da ecclesia como também obtinha a própria elevação espiritual. E o mais conveniente do ponto de vista da hierarquia episcopal: tudo isso podia ser alcançado sem que a mulher tivesse que se expor publicamente. Muito pelo contrário, era imperioso que as mulheres chamadas à causa cristã guardassem o recato, a discrição e o respeito às autoridades masculinas. Podemos aventar a hipótese de que esse ideal de exercício silencioso e reservado do ascetismo feminino se realizou em sua plenitude no movimento monástico, quando a criação das comunidades cenobíticas propiciou um autêntico apartheid sexual, como constatamos na História Lausíaca. 
Sabemos, pelo testemunho de Paládio, que os mosteiros femininos de Tabenesi, no Alto Egito, se localizavam do outro lado do Nilo, em oposição aos mosteiros masculinos. Os homens estavam proibidos de visitar os mosteiros femininos, com exceção dos superiores religiosos, que o faziam apenas aos domingos. As monjas, por sua vez, eram proibidas de ver ou falar com um homem. A importância dessa regra pode ser avaliada por meio de um episódio trágico que teve lugar muito provavelmente no mosteiro pacomiano de Tismene. Numa certa ocasião, um alfaiate, tendo cruzado o rio por ignorância, veio dar às portas do mosteiro em busca de serviço. Uma jovem irmã, encontrando-o por acaso, despediu-o com a justificativa de que o mosteiro possuía seus próprios alfaiates. A breve conversa foi testemunhada por outra irmã, que se apressou em difundir a notícia perante a irmandade. A monja caluniada, não suportando a acusação de malícia, terminou por se afogar no rio. A caluniadora, atormentada pela própria consciência, decide fazer o mesmo. Os dois suicídios consecutivos são reportados ao sacerdote, que proíbe a celebração da missa em intenção das suicidas e decreta, para as monjas coniventes com a calúnia, a excomunhão pelo prazo de sete anos, pois se revelaram inábeis em manter a paz no mosteiro. ${ }^{32}$ A partir desse caso, é possível se avaliar a intensidade da ruptura com os laços de sociabilidade entre os sexos imposta às monjas que ingressavam na vida monástica, uma imposição inédita até então. De fato, antes da instituição do monacato feminino, as mulheres não se encontravam sujeitas a nenhuma disciplina tão rigorosa como esta no que dizia respeito à relação com o sexo oposto, razão pela qual podemos supor que o monacato representou uma notável domesticação do potencial feminino, que agora se encontrava enclausurado e ao mesmo tempo regulado num ambiente concebido como à parte do mundo e, de certo modo, oposto ao próprio mundo. Em seu interior, a vigilância sobre o comportamento individual é exercida não apenas pela amma, a superiora, mas igualmente por cada uma das irmãs e pela irmandade em seu conjunto, o que torna o mosteiro uma notável instituição de controle e regulação da conduta feminina. E para o caso de tais mecanismos de controle se revelarem insuficientes, havia sempre a possibilidade de intervenção por parte de um superior masculino.

Muito embora na História Lausíaca não faltem exemplos que sustentem a idéia de que o monacato significou a realização plena do ideal de segregação sexual continuamente reiterado pela literatura eclesiástica a partir do século III, é preciso reconhecer que Paládio, ao contrário de muitos dos seus contemporâneos, não é partidário do argumento segundo o qual homens e mulheres não poderiam, vivendo lado 
a lado, exercitar a virtude. Na época de Paládio vigorava na Igreja uma intensa polêmica em torno da coabitação de ascetas do mesmo sexo, costume bastante difundido no Oriente, mas que nem por isso deixava de suscitar a reprovação de muitos líderes religiosos, a exemplo de João Crisóstomo e Nestório. Tanto que Epifânio de Salamina, ao elaborar o Panarion, um exaustivo inventário de heresias, inclui nele um movimento denominado messalianismo, cujas origens remontam à segunda metade do século IV. O messalianismo (de messalien, um termo siríaco que significa "aquele que ora”) tem como berço a Mesopotâmia, difundindo-se em seguida para a Síria e a Ásia Menor. Em 381, o Concílio de Antioquia condena os ascetas messalianos por permitirem a coabitação de homens e mulheres. ${ }^{33} \mathrm{O}$ messalianismo e seus congêneres representavam, sem dúvida, o último obstáculo a ser removido para a concretização definitiva da separação entre os sexos no final da Antigüidade. Nessa polêmica, no entanto, Paládio se inclina muito mais a favor dos messalianos ao evocar, na História Lausíaca, o exemplo de Orígenes e Atanásio, que, forçados a fugir, foram acolhidos por virgens que os protegeram e sustentaram por anos a fio. Segundo o autor, esses episódios foram inseridos na obra a fim de permitir a todos saber "que é possível obter distinção de muitas maneiras, se assim o desejarmos”. ${ }^{34}$

Não obstante a preocupação de Paládio em reafirmar a diversidade de experiências religiosas que poderiam conduzir os ascetas rumo à virtude, o que inclui a coabitação entre os sexos, asperamente combatida em sua época, não podemos deixar de reconhecer o quanto as devotas cristãs ocupam, no conjunto da História Lausíaca, uma nítida posição secundária. Lembradas como piedosas, generosas, belas, obedientes e laboriosas, as mulheres sem dúvida apresentam um conjunto de atributos que fazem delas monjas excelentes e, em alguns casos, exemplos de virtude para os próprios homens. E é só. Sua capacidade efetiva de liderança religiosa é mínima, mesmo no caso das kanonikai, sempre dependentes de um conselheiro espiritual do sexo masculino que as acompanha. Como vimos, dentre os casos narrados por Paládio apenas Piamon se notabiliza por executar atos taumatúrgicos, ao passo que dentre todas as mulheres mencionadas somente Sabaniana é identificada como diaconisa, embora tenhamos conhecimento de que o diaconato feminino no Oriente era uma instituição reconhecida pelos meios eclesiásticos. A atuação das mulheres na História Lausíaca se exerce invariavelmente em dois planos: ou no recinto do convento, encontrando-se a monja em estado de devoção permanente, ou no saeculum, executando obras de caridade. Talvez a evidência mais contundente da posição subalterna das ascetas diante dos seus colegas 
masculinos resida no fato de que apenas Alexandra é lembrada como anacoreta. Sabemos que no monacato primitivo os ascetas que praticavam a anacorese gozavam de um prestígio superior entre os Padres do Deserto. Para Markus, ${ }^{35}$ isso se devia à antiga dicotomia entre vida contemplativa e vida ativa própria do pensamento antigo. No entanto, é forçoso reconhecer que os anacoretas eram amiúde celebrados como seres miraculosos capazes de proezas sobrenaturais, o que significava, na sociedade romana tardia, uma habilidade privilegiada por envolver a atualização do sagrado sobre a terra. Em virtude disso, os anacoretas logo viam surgir em torno de si um culto próprio, sendo em muitas ocasiões convocados a prestar serviços à corte imperial, o que dá bem a medida do prestígio que detêm. Às mulheres, entretanto, essa experiência de manipulação do sagrado, de produção de maravilhas a exemplo do exorcismo, era algo excepcional. Tal constatação vem a tornar evidente o êxito alcançado pela hierarquia cristã do Baixo Império no esvaziamento cabal dos dons carismáticos revestidos pelas mulheres, produzindo-se, na Igreja, uma situação de desigualdade entre homens e mulheres que mutatis mutandi perdura até os nossos dias.

SILVA, Gilvan Ventura da. Asceticism, gender and power in the Late Roman Empire: Palladius and the status of the holy women. História, São Paulo, v. 26, n. 1, p 82-97, 2007.

\begin{abstract}
The several kinds of female asceticism observed in the Roman Empire during the first three centuries A.D. will be gathered in a new religious experience that begins around 270 A.D.: the monasticism. Throughout the analysis of the Lausiac History, written by Palladius, bishop of Hellenopolis, in Bitinia, we aim at researching about the female ascetics social position and their actions as monastic movement members. Besides, we reflect over the kind of power women could exercise in their local communities compared with the holy men.
\end{abstract}

Keywords: Late Roman Empire, Palladius, Female Asceticism

Artigo recebido em 04/2007. Aprovado em 06/2007.

\title{
NOTAS
}

\footnotetext{
* Professor de História Antiga do Departamento e do Programa de Pós-Graduação em História - Centro de Ciências Humanas e Naturais - UFES - 29075-710 - Vitória/ES. E-mail: gil-ventura@uol.com.br
} 

${ }^{1}$ No Egito, o termo anachoresis designava originalmente a fuga para o deserto daqueles perseguidos pelo
fisco, pela justiça ou pelos credores. Com a ascensão do movimento, a anacorese passa a identificar a
opção do asceta pela vida solitária no deserto. Já o cenobitismo deriva de coenobium (convento,
mosteiro) e identifica a prática do ascetismo em comunidade mediante a observância de uma regra
(MARAVAL, 1995, p.722 e ss.).

2 ATANÁSIO. Contra os pagãos; A encarnação do Verbo; Apologia ao imperador Constâncio; Apologia de sua fuga; Vida e conduta de S. Antão. São Paulo: Paulus, 2002.

${ }^{3}$ BIARNE. Moines et rigoristes em Occident. In: MAYEUR, J. M. et al. Histoire du christianisme. Paris: Desclée, 1995. t.II, p.765,

${ }^{4}$ A difusão do monacato cenobítico não significou evidentemente a supressão imediata das antigas modalidades de associação entre as virgens, incluindo a coabitação de ascetas de sexos diferentes, o que suscitou em finais do século IV a vívida reprovação de João Crisóstomo. MARAVAL, P. Le monachisme oriental. In: MAYEUR, J. M. et al. Histoire du christianisme. Paris: Desclée, 1995. t.II, p.719-745.

${ }^{5}$ ALEXANDRE, M. Do anúncio do Reino à Igreja. Papéis, ministérios, poderes femininos. In: DUBY, G. \& PERROT, M. (Org.). História das mulheres. Porto: Afrontamento, 1993. v.1 - A Antigüidade, p.543.

${ }^{6}$ ANDERSON, G. Sage, saint \& sophist; holy men and their associates in their early Roman Empire. London: Routledge, 1994. p.54.

${ }^{7}$ MARKUS, R. A. O fim do cristianismo antigo. São Paulo: Paulus, 1997. p.162. BLÁZQUEZ, J. M. et al. Cristianismo primitivo y religiones mistéricas. Madrid: Cátedra, 1995. p.391.

${ }^{8}$ BROWN, P. Il culto dei santi. Torino: Einaudi, 1983. p.16 e ss. Para uma descrição arqueológica acerca das condições de vida dos monges no deserto egípcio, consultar: ZAFFANELLA, G. C. Eremiti nel deserto d'Egitto. Archeologia Viva, n.62, p.54-65, 1997.

${ }^{9}$ LACARRIÈRE, J. Padres do deserto, homens embriagados de Deus. São Paulo: Loyola, 1996. p.102.

${ }^{10}$ BERARDINO, A. Dicionário patrístico e de antigüidades cristãs. Petrópolis: Vozes, 2002. p.1062.

${ }^{11}$ BROWN, P. Corpo e sociedade. Rio de Janeiro: Jorge Zahar, 1990. p.222.

${ }^{12}$ PALLADIUS. The Lausiac history. Translated by W. K. Lowther Clarke. London: The MacMillan Company, 1918, LXI.

${ }^{13}$ Idem, XLI.

${ }^{14}$ Idem, XLIV.

${ }^{15}$ Idem, XLVI e LIV.

${ }^{16}$ ALEXANDRE, M. Op. cit., p.516.

${ }^{17}$ PALLADIUS. Op. cit., V.

${ }^{18}$ Idem, LIX.

${ }^{19}$ Idem, XXXI.

${ }^{20}$ BROWN, P. Genèse de l'Antiquité Tardive. Paris: Gallimard, 1984. p.38-9.

${ }^{21}$ MONTSERRAT, D. Reading gender in the Roman world. In: HUSKINSON, J. Experiencing Rome; culture, identity and power in the Roma Empire. London: Routledge, 2000. p.154.

${ }^{22}$ UNTERMAN, A. Dicionário judaico de lendas e tradições. Rio de Janeiro: Jorge Zahar, 1992. p.184.

${ }^{23}$ CONDE GUERRI, E. La mujer "ideal” en el Pedagogo de Clemente Alejandrino. In: Actas de las V Jornadas de Investigación Interdisciplinaria. Madrid: Universidad Autónoma de Madrid, 1986. p.332.

${ }^{24}$ MARCOS SANCHEZ, M. La visión de la mujer en San Jeronimo a través de su correspondencia. In: Actas de las V Jornadas de Investigación Interdisciplinaria. Madrid: Universidad Autónoma de Madrid, 1986. p.317- 98.

${ }^{25}$ PALLADIUS. Op. cit., XXXIV.

${ }^{26}$ Idem, XLI.

${ }^{27}$ Idem, XXXIV.

${ }^{28}$ Idem, LX.

${ }^{29}$ PAGELS, E. Os evangelhos gnósticos. São Paulo: Cultrix, 1995. p.90.

${ }^{30}$ ALEXANDRE, M. Op. cit., p.542.

${ }^{31}$ Uma evidência suplementar da retirada progressiva das mulheres do espaço coletivo pode ser encontrada no reconhecimento da virgindade como a principal alternativa para o martírio, concepção que se afirma no século III. MARKUS, R. A. Op. cit., p. 80.

${ }^{32}$ PALLADIUS. Op. cit., XXXIII.

${ }^{33}$ MARAVAL, P. Op. cit., p.737-8.

${ }^{34}$ PALLADIUS. Op. cit., LXIV.

${ }^{35}$ MARKUS, R. A. Op. cit., p.183. 